The ACRL Professional Association Liaison Committee invites proposals for funding and uses the following guidelines for distribution of financial support.

\section{Criteria:}

1. Support for participation in organizations could include activities such as major presentations, panel discussions, poster sessions, publications of articles and more. In awarding the funding request, the committee will give weight to the significance of the contribution.

2. Preference will be given to efforts which contribute to the understanding or use of academic library resources or services. Also eligible for funding are efforts which enhance the perception of academic librarians as part of "the education team."

3. Must be an ALA member, with preference given to ACRL members.

4. Adequate documentation must be provided and should include all points listed in the format suggested below.

\section{Methods:}

1. Funding will be up to $\$ 300$ of costs not covered by others for travel, accommodations, and registration (not membership).

2 . There is no limit on the number of grants that may be awarded to an individual.

3. Funding will be awarded after the event, but requests may be submitted for approval prior to the event. Awards are dependent on the committee receiving a report of activity.

4 . The committee may request information suitable for publication within six months after the event.

5. The committee meets twice a year to review applications: at ALA Midwinter and Annual Meetings.

Please send applications to: Jacquelyn M. Morris, Chair, ACRL Professional Association Liaison Committee, Mary Norton Clapp Library, Occidental College, 1600 Campus Road, Los Angeles, CA 90041.

\title{
Strategic planning for ACRL
}

\author{
By the ACRL Planning Committee
}

Carolyn Dusenbury, Chair

\section{The annual report of ACRL's Planning Committee.}

T his is the first of a series of annual Strategic Planning reports to the ACRL membership. Because the planning process is still relatively new to the Association, this report provides an overview the ACRL Strategic Plan, describes briefly how the planning process operates, and attempts to answer some of the most frequently asked questions.

\section{Overview}

The ACRL Strategic Plan is the result of six years of work by two ACRL task forces, the Task Force on an Activity Model for the 1990's (1980-1982) and the Strategic Planning Task Force (1984-1986). To aid in the development of the plan, a large-scale needs assessment was conducted by mail and the plan was the focus of the $1985 \mathrm{An}$ nual Membership meeting. Membership involvement was crucial in establishing both the directions and goals of ACRL.

The Strategic Plan consists of several parts: a mission statement, four broad goals (e.g., "To contribute to the total professional development of academic and research librarians"), with subgoals for each goal (e.g., "To sponsor and encourage opportunities for...librarians to update existing compe- 
tencies, learn requisite new skills, and gain awareness of the state-of-the-art"). Specific objectives are enumerated under each subgoal, and strategies are developed over a 3-year period to accomplish objectives. The plan also indicates which units are involved in activities that contribute toward accomplishment of the objectives, and identifies any resources that are necessary to meet them.

The Strategic Plan is an ongoing process. It is never finished, because the work of the Association is never finished; as the needs of the membership change and the environment in which they work evolves, the plan is updated to reflect new priorities and changing situations. At the end of each year, the first year of the 3-year cycle is replaced with an updated plan for the second year, and a third year is added in a continuous cycle.

Because the four goals are broad, overall directions for the Association, almost all of the ongoing activities of ACRL chapters, committees, sections and other units are reflected in the broad framework of the goals and subgoals. Most of the changes that will occur in the plan are seen in the objectives and strategies that are developed.

\section{The planning process}

The planning process is designed to encourage input from all levels within the Association. The ACRL Board of Directors is responsible for setting annual priorities. The Planning Committee is responsible for monitoring and extending the plan by using all of the information they gather from the Association and through biennial environmental scans and membership needs assessments.

The membership plays a major role in the design and content of the Strategic Plan. As part of the annual planning review and updating process, the Planning Committee asks each ACRL standing committee, section, and task force to review its activities and fill out a strategic planning inventory. This information enables the Planning Committee to monitor the plan for current activities that contribute to the goals and to extend the plan into the future. The inventory also identifies areas or activities that are not included in the current plan and need to be added to it so that the plan is responsive to changing member needs. Chapters are also asked to review their activities and identify unmet needs, and individual members are invited to communicate with the Planning Committee with their thoughts and concerns. All of this information is vital to the Planning Process.

One of the products of the planning process is the Annual Operating Plan, which is produced by ACRL staff using the priorities set by the President and the Board of Directors, the inventories submitted by units, reports from chapters, and the staff's knowledge of ongoing Association commitments, such as national conferences. The Operating Plan includes anticipated activities of ACRL units, details of the ACRL budget and the Executive Director's overview of the year being planned. The Op- erating Plan is reviewed by the Planning Committee and presented to the Board of Directors for final approval.

\section{Planning concerns}

In discussions with units and members, the Planning Committee members have heard a few concerns more than a few times. A few points of clarification may be helpful.

Since the Strategic Plan was adopted, all we ever hear is plan, plan, plan. Are we just planning to plan, or will we ever see any results?

Because the process is less than two years old and represents a genuine change for ACRL, no one has the temerity to suggest that the Strategic Plan is a well-oiled machine. The plan is new to everyone and subject to some trial and, probably, some error. This is not unique to the ACRL plan. Experience with strategic planning in libraries and other organizations suggests that, at first, planning seems to be just another job to add to an already long list. But once the process is understood and absorbed into ongoing activities, it forms a framework in which to operate-rather than an obstacle to climb over before anything else can get done. The Planning Committee is actually aware of the need to minimize redundant or unnecessary bureaucracy, and as the process develops, will continue to welcome suggestions for improvement.

Some of the activities that have already resulted from the planning process include: 1) an assessment of membership needs for continuing education (see C $\triangleleft R L$ News, April 1987, p. 196, for the results); 2) the establishment in 1987 of an ACRL task force on awards; and 3) the publication of an output measures manual, currently in preparation by a professional consultant.

Does the plan affect the ability of ACRL units to set their own agendas?

No. The plan is designed to be sufficiently broad to encompass the interests expressed by the membership. Reports from units will enable the Association to demonstrate the many ways that unit activities meet the objectives of the plan. Occasionally when new priorities are set, units may be asked by the Board of Directors to undertake a task to address these priorities; but it will be a request that will involve negotiation with the unit and will include a provision for increasing the resources needed by the unit to accomplish the task. New task forces will also be established to work on some of the tasks, thus providing a chance for increased participation by ACRL members.

Will ACRL fund projects that are not in the Strategic Plan?

Again, in most cases there is a place in the plan for all requests for resources. If this is not the case, there is a good chance that the plan needs to be reviewed to reflect legitimate new ideas. The plan is designed to change and expected to do so. Requests that challenge the plan will be one of the primary ways of keeping the plan moving ahead. 
How will I have the opportunity to comment on the Strategic Plan?

In subsequent annual reports of this committee, the membership will be informed of the specific priorities identified by the Board, which objectives have been accomplished and what new objectives have been added. Members will be invited to communicate with the Planning Committee regarding the progress of the Strategic Plan. This, along with the feedback from chapters, committees, sections, and other units should provide all interested members with an opportunity to be involved with the overall direction of ACRL.

If you would like a copy of the Strategic Plan, please contact the ACRL office. If you would like to comment on the plan, contact any member of the Planning Committee or the ACRL office and they will forward your comments to the chair of the Planning Committee.

\title{
Guidelines for conservators
}

\section{and curators: Draft III}

\author{
Prepared by the RBMS Ad Hoc Conservators' Collations Committee \\ Terry Belanger, Chair
}

\section{Collations and marking in special collections.}

\begin{abstract}
$\mathbf{T}$ charge was to study the current use of collational formulae by conservators and curators, and (if it thought it wise to do so) to produce guidelines encouraging the joint, standardized use of such formulae by conservators and curators.
\end{abstract}

\section{The story so far}

The Committee was formed by action of the RBMS Executive Committee at Annual Conference 1984 (Dallas). It had its first meeting at Midwinter 1985 (Washington, D.C.). Members were formally appointed to the Committee in the spring of 1985 by the then chair of the Section, Lynda Corey Claassen (San Diego). At the July 1985 Annual Conference (Chicago), Committee members discussed the first draft of questionnaires to be sent out to conservators and curators, and at Midwinter 1986 (Chicago) the Committee approved the text of these questionnaires, which were sent out in the spring of 1986 to 54 conservators and to about 60 curators.

The heavy response was read by the Committee at Annual Conference 1986 (New York), and the chair of the committee was directed to prepare draft guidelines. The first draft of these guidelines was discussed at Annual Conference 1987 (San Francisco), and the chair was directed to prepare a second draft of the guidelines for further discussion at Midwinter 1988 (San Antonio). Further revisions were made at this meeting, and a final version approved for transmission to the RBMS Standards Committee. This final version is given here.

\section{Recommendations}

1. Curatorial collations. Curators should routinely collate books, or make copies from department records of previously done collations, before sending them away for treatment, and a copy of these collational statements should accompany the material being sent. 